\title{
REPRODUCIBLE INDUCTION OF CAVITY SPOT IN CARROTS AND PHYSIOLOGICAL AND MICROBIAL CHANGES OCCURRING DURING CAVITY FORMATION
}

\author{
Edith SOROKer, Yoav Bashan* and YaACOV OKON \\ Department of Plant Pathology and Microbiology, The Hebrew University of Jerusalem, Faculty of \\ Agriculture, P.O. Box 12, Rehovot 76100, Israel
}

(Accepted 14 March 1984)

\begin{abstract}
Summary-Inoculation of carrots with 40 types of bacteria, both aerobic and anaerobic, including clostridia isolated from cavity spots, failed to induce cavity spot in carrots. A combined stress of minimum $6 \mathrm{~h}$ flooding and temperatures higher than $28^{\circ} \mathrm{C}$ clearly induced cavity formation. Sugars, amino acids, lipids and minerals leaked from the carrots after flooding and heating the roots. A longer growth period following stress markedly increased cavity spots. Soil types (sandy loam and loess) and several carrot cultivars tested had no marked effect on spot formation. Cavities were formed in stressed carrots grown in sterilized soil containing only one type of bacterium, a Gram-negative short rod. Scanning electron micrographs revealed that after carrots were subjected to combined stress, microscopic cavities nearly free of bacteria were formed under the epidermis. Proliferation of bacteria was concommitant with the appearance of visible cavities. Cell-free extracts of infected carrots showed higher protease and pectinase-specific activities, as well as significantly higher peroxidase and polyphenoloxidase activities and total phenol content as compared to healthy carrots.
\end{abstract}

\section{INTRODUCTION}

Cavity spot of carrots (Perry and Harrison, 1979a) is an important factor limiting production in all cultivated areas of Israel. Crop losses have been reported from Scotland, England and U.S.A. So far, means for reducing crop damage in Israel have not been implemented. The main obstacle has been an absence of knowledge of the causal agent and the conditions affecting cavity spot formation. Attempts to induce the phenomenon regularly under controlled conditions have been unsuccessful. Nevertheless, the importance of some factors in the formation of cavity spots, such as climatic conditions (Grogan et al., 1961; Scaife and Clarkson, 1978), insufficient drainage (Guba et al., 1961), temporary anaerobic conditions (Perry and Harrison, 1979a,b), presence of anaerobic bacteria (Perry and Harrison, 1977), lack of calcium (Maynard et al., 1963), presence or absence of ammonium ions (Scaife et al., 1980) and soil structure (Perry and Harrison, 1979b), have been suggested but not confirmed (Lund, 1982). Furthermore, the partial contribution of each of the above factors has not been properly evaluated (Lund, 1982).

We describe factors affecting the formation of cavity spots and physiological and microbial changes occurring during the process of cavity formation. An abstract of this paper has been presented by Finkelstein et al. (1983).

\section{MATERIALS AND METHODS}

\section{Organisms and growth conditions}

Carrots (Daucus carota L. var. sativa) cv. Tip-top (Sluis and Groot Co., Holland) and cv. Tito (Elite-

*Present address: Department of Plant Genetics, The Weizmann Institute of Science, Rehovot 76100, Israel.
Zaden, Holland) were used in most experiments. The cultivars, Fanci (Ohlsens Enke, Denmark), Slendero (Royal Sluis, U.K.), and Scarlet (Keystone, U.S.A.) were used in one experiment.

Seeds were disinfected by immersion first in $70 \%$ ethanol for $30 \mathrm{~s}$, then in $1 \% \mathrm{NaOCl}$ for $30 \mathrm{~s}$, both under vacuum. They were then washed 5 times with sterile distilled water.

Seeds were sown in plastic pots, $10 \mathrm{~cm}$ high $\times 10 \mathrm{~cm}$ dia. The pots were filled with $600 \mathrm{~g}$ of Loess raw soils (camborthids, Xerollic camborthids) or brown-red degrading sandy soils (Haploxeralfs, Typic Haploxeralfs). Plants were fertilized every 2 months with $0.5 \% 20: 20: 20 \mathrm{~N}: \mathbf{P}: \mathbf{K}$ commercial fertilizer (Haifa Chemicals, Israel). The plants were grown in a glasshouse during the winter and under a shadow net in the summer. Plants were also grown under aseptic conditions in an inverted Leonard's bottle assembly (Vincent, 1970) containing Hoagland solution and sterilized by gamma-irradiation (2.5 Mrad using a cobalt 60 source). Disinfected seeds were sown under aseptic conditions and the soil was covered with a layer of sterile waxed sand. Plants in Leonard's jars were fertilized with $0.75 \mathrm{ml}$ $0.5 \% \mathrm{FeSO}_{4}$ solution under aseptic conditions, and grown under controlled environmental conditions in a growth chamber with a photoperiod of $16 \mathrm{~h}$ at a bench-level light intensity of $350 \mu \mathrm{E} \mathrm{m}^{-2} \mathrm{~s}^{-1}$ at $20^{\circ} \pm 2^{\circ} \mathrm{C}$

Bacteria were isolated from cavity spots of carrots, under aerobic or anaerobic conditions (in anaerobic cell, $\mathrm{H}_{2}+\mathrm{CO}_{2}$ atmosphere, [BBL, U.S.A.) in yeast peptone medium (YP) (Bashan et al., 1978), nutrient agar (NA) (Difco), King-B medium (King et al., 1954) and in yeast peptone sucrose medium (YPS) (Hobbs et al., 1971).

Spore-forming-bacteria (Gram-positive rods, possibly Bacillaceae) were isolated by slicing carrot seg- 
ments containing cavity spots and shaking them vigourously in a saline solution $(0.85 \% \mathrm{NaCl})$ for $30 \mathrm{~min}$ at $30^{\circ} \mathrm{C}$. The solution was then filtered and boiled for $10 \mathrm{~min}$. Bacteria were cultured either aerobically or anaerobically as described above. Bacterial cultures were maintained on YP or YPS media.

\section{Inoculation of carrots}

Carrots were disinfected with $0.5 \% \mathrm{NaOCl}$ for $30 \mathrm{~s}$ and washed 5 times with sterile distilled water. Yeast peptone sucrose liquid cultures ( $24 \mathrm{~h}$ old) containing $10^{8}$ colony forming units $(\mathrm{cfu}) \mathrm{ml}^{-1}$ of each bacterial isolate (18 aerobes, 12 anaerobes and 10 sporeforming anaerobes) were used to inoculate the carrots by: (a) soaking them in bacterial suspension (b) slow injection of $1 \mathrm{ml}$ suspension into the tissue, or (c) injuring carrots with a sterile knife and placing $0.1 \mathrm{ml}$ bacterial suspension on the wound. After inoculation, the carrots were incubated at room temperature in humid chamber for 2 weeks. In a further treatment (d) all aerobic and anaerobic isolates $(100 \mathrm{ml}$ each), containing about $10^{8} \mathrm{cfu} \mathrm{ml}^{-1}$ were mixed and added to the soil pots with mature carrots $(50 \mathrm{ml}$ per pot).

Bacteria were counted by the dilution-plate method. Ten $\mathrm{g}$ of carrots or soil (in ten replicates) were shaken in $90 \mathrm{ml}$ sterile saline for $120 \mathrm{~min}$. Colonies were counted on plates with fewer than 200 colonies after incubation at $25^{\circ} \pm 3^{\circ} \mathrm{C}$ on YPS or on NA medium until colony formation.

\section{Exposure of carrots to environmental stresses}

Pots containing 5-month-old carrot plants were immersed for $36 \mathrm{~h}$ in water baths, each at a different constant temperature $\left(7^{\circ}-40^{\circ} \mathrm{C}\right)$. Leaves and the upper part of the hypocotyl were kept above water level. The pots were then held in the greenhouse for 4 weeks. Alternatively, the pot soil surface was covered with a $0.5 \mathrm{~cm}$ layer of vermiculite and a $2-3 \mathrm{~mm}$ layer of wax (Perry and Harrison, 1977). The plants were then flooded from the bottom up by placing them in a container of water.

Leonard's jar assemblies containing 5-month-old plants were filled aseptically with sterile Hoagland solution until the root system was flooded but the upper waxy sand remained dry. They were then incubated at $30^{\circ} \pm 1^{\circ} \mathrm{C}$ for $36 \mathrm{~h}$. After incubation, $100 \mathrm{ml}$ of solution were removed aseptically from the jar, and the plants were held in a growth chamber for 1 month at $20^{\circ} \pm 2^{\circ} \mathrm{C}$.

The plants were exposed to various temperatures in ventilated incubators or consecutively to wilting and flooding stresses.

Different potassium and nitrogen levels in soil were obtained as shown in Results, Table 2.

\section{"Disease" index}

After carefully washing the carrots, "disease" severity (Fig. 1) was determined according to the following scale: $0=$ no visible cavities; $1=$ up to three cavities, each smaller than $2 \mathrm{~mm}$ dia; $2=$ more than three cavities smaller than $2 \mathrm{~mm}$, or up to three cavities $2-10 \mathrm{~mm}$ dia; $3=$ more than three cavities larger than $2 \mathrm{~mm}$ or at least one cavity larger than $10 \mathrm{~mm}$ dia "disease" index was calculated as follows:

$$
\text { D.I. }=\sum_{i=0}^{3}(N i \times i) N \text { total }^{-1}
$$

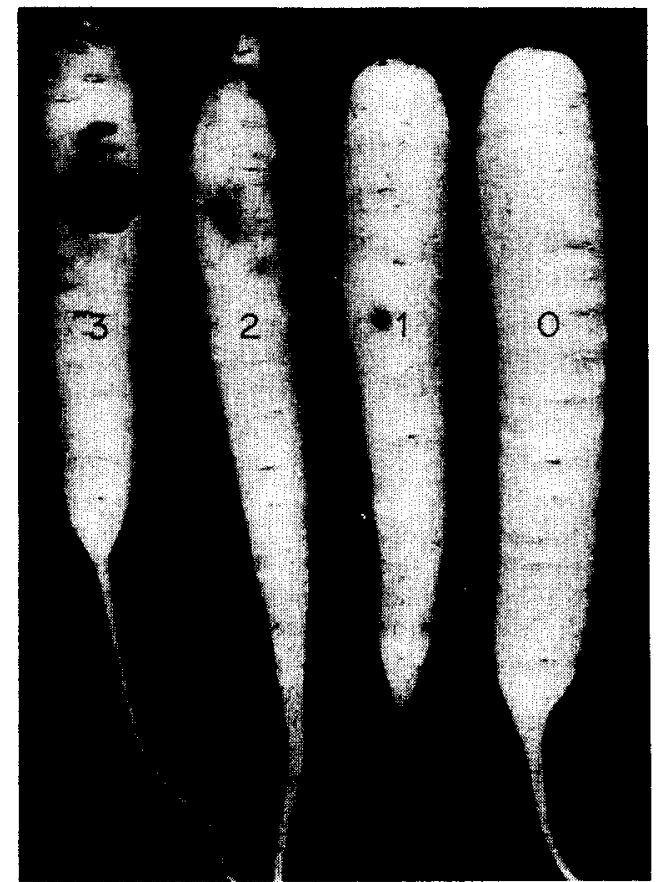

Fig. 1. "Disease" index of cavity spot of carrots.

where $i=$ disease severity, $N=$ total number of carrots tested, $N i=$ number of carrots with disease level $i$.

\section{Enzyme extractions}

Mature carrots were separated into healthy carrots $(D . I .=0)$ and carrots with cavities (D.I. $=2$ or 3 ). Segments of external tissue $(1.5 \times 0.5 \mathrm{~cm}$ area, $0.5-1.5 \mathrm{~mm}$ cross section) were removed from mature healthy carrots and from "diseased" carrots either from a necrotic spot or from apparently healthy tissue near the cavity spot. The segments were homogenized in an ice bath in $60 \mathrm{~mm}$ phosphate buffer (pH 6.5; $3 \mathrm{ml} \mathrm{g}^{-1}$ tissue) with an Ultra-turrax homogenizer (Janke and Kunkel), then in an Omnimixer (Sorvall), again with Ultra-turrax, and finally with a fine homogenizer (Elda). The homogenate obtained was centrifuged at $12,000 \mathrm{~g}$ for $10 \mathrm{~min}$, and the supernatant centrifuged twice at $30,000 \mathrm{~g}$ for $30 \mathrm{~min}$. The supernatants obtained served as enzyme sources.

\section{Enzyme assays}

Polygalacturonase (Nasuno, 1975; Wang and Keen, 1970), pectin-lyase and pectin-methylesterase (Nasuno, 1975) and pectate lyase (Nasuno and Starr, 1967) were tested. All the pectinases reactions were run for $4 \mathrm{~h}$ at $35^{\circ} \mathrm{C}$. During incubation, a drop of toluene was placed on the surface of the reaction mixture to prevent bacterial contamination. Controls consisted of reaction mixtures without enzyme, without substrate, reaction mixtures that were autoclaved for $20 \mathrm{~min}$, and reaction mixtures to which the enzyme was added just before testing.

Cellulase (Benefield, 1971) and protease (Rinderknecht et al., 1968) were tested. Extracts for assaying peroxidase and polyphenoloxidase activities were 
partially purified by mixing with $5 \%$ active charcoal and filtering through Whatman No. 42 filter paper. Peroxidase (Lee, 1973) and polyphenoloxidase (Leonard, 1971) were determined.

\section{Electrolyte leakage from carrots}

Ten healthy carrots were thoroughly washed with double distilled water and incubated at various temperatures with or without immersion in $250 \mathrm{ml}$ of double distilled water. After $36 \mathrm{~h}$ of incubation, the carrots were transferred to $250 \mathrm{ml}$ double distilled water, and electric conductivity of $1 \mathrm{ml}$ of the above solution was measured using Radiometer CDM 2b conductivity bridge. The leakage of constituents was tested in the solution after lyophilization to dryness and storage at $-20^{\circ} \mathrm{C}$.

\section{Analytical procedures}

Proteins were measured by the Coomassie brilliant blue G-250 method (Sedmak and Grossberg, 1977) using bovin serum albumin and chymotrypsin (Sigma Chemical Co., U.S.A.) as standards, and by anthrone or glucostate (Sigma) methods (Johanson, 1954) for sugar analysis, using glucose as standard. Fatty acids were detected by gas chromatography (Ruben et al., 1981), and amino acids in an amino acid analyser (Dionex D-502). Total carbon was measured by the sulphuric acid method (Johnson, 1949) using glucose as standard, and phosphorous was measured by the ascorbic acid method (Watanabe and Olsen, 1965) using $\mathrm{KH}_{2} \mathrm{PO}_{4}$ as standard. Sodium and potassium were detected by a flame photometer (Corning 420) using $\mathrm{KCl}$ and $\mathrm{NaCl}$ as standards. Calcium and magnesium were detected by atomic absorption (Perkin-Elmer 2380) using $\mathrm{CaCl}_{2}$ and $\mathrm{MgCl}_{2}$ as standards. $\mathrm{NO}_{3}$ was measured with a nitrogen electrode (Orion) using $\mathrm{KNO}_{3}$ as standard. Phenols were measured by $\mathrm{FeCl}_{2}-\mathrm{K}_{3} \mathrm{Fe}(\mathrm{CN})_{6}$ method (Kritzman and Chet, 1980) using catechol as standard.

\section{Scanning electron microscopy (SEM)}

Surface segments of carrots at various stages of cavity formation were sliced and prepared for observation using 5 to 6 samples per treatment (Bashan $e t$ al., 1978).

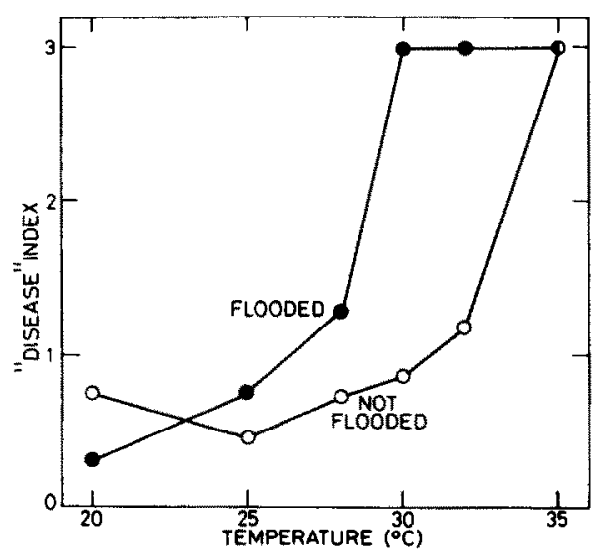

Fig. 2. Effect of flooding and temperature on cavity spot severity.

\section{Experimental planning and statistical analysis}

Experiments dealing with exposure of carrots to environmental stresses were conducted 2 or 3 times. Treatments consisted of 20 pots with two carrots per pot arranged in a randomized fashion. Experiments dealing with enzymatic analysis were conducted 3 times. Samples for enzymatic analysis were taken in triplicate from different areas of the carrots, with two replicates per sample. Results presented are from representative experiment. Correlations for "disease" severity were done by calculating linear regression. Significance was determined at $P \leqslant 0.05$, or by standard error.

\section{RESULTS}

Induction of cavity spot by inoculation with various bacterial isolates

The following bacterial isolates, all isolated from cavity spots of carrots, were used in this work:

(1) Eighteen aerobic bacterial isolates

- 11 Gram-negative rods with cream, white, yellow, orange or red colonies

-3 Gram-positive coccus in pairs and tetrads forming white, yellow or cream colonies

-4 Gram-positive rods forming white or cream colonies with smooth or rough edges.

(2) Twelve anaerobic bacterial isolates

8 Gram-positive rods

-4 Gram-negative rods

(3) Ten anaerobic spore-forming Gram-positive rods

-(possibly Bacillus sp. or Clostridium sp. slightly differing from each other in morphology and colony characteristics).

These 40 isolates obtained from cavity spots were used separately or in mixtures to inoculate mature healthy carrots by the three inoculation methods. No typical cavity spots were formed in any of the inoculated carrots during 14 days at $28^{\circ} \pm 2^{\circ} \mathrm{C}$ in a humid chamber. After 14 days, most of the carrots started to rot.

\section{Effect of various environmental stresses on cavity spot formation}

Carrot plants grown in sandy loam soil in pots for 4 months were exposed to the following stresses for $36 \mathrm{~h}$ : (a) wax layer on the soil surface and flooding; (b) flooding combined with incubation at different temperatures (c) incubation at different temperatures; and (d) three successive cycles of flooding $(36 \mathrm{~h})$ and drying $(96 \mathrm{~h})$ until plants wilted. Plants growing normally in the greenhouse were used as controls. After the plants had been stressed, two pots from each treatment were immediately checked for cavity spots. The remaining plants were further incubated for up to 5 weeks in the greenhouse.

Cavity spots appeared mainly after 5 weeks in all the plants flooded at $30^{\circ} \mathrm{C}$ (Fig. 2). No apparent changes were observed in any carrots immediately after they had been stressed. Controls generally showed a D.I. of 0-0.5 units. Application of stresses to plants at temperatures higher than $35^{\circ} \mathrm{C}$ or by 


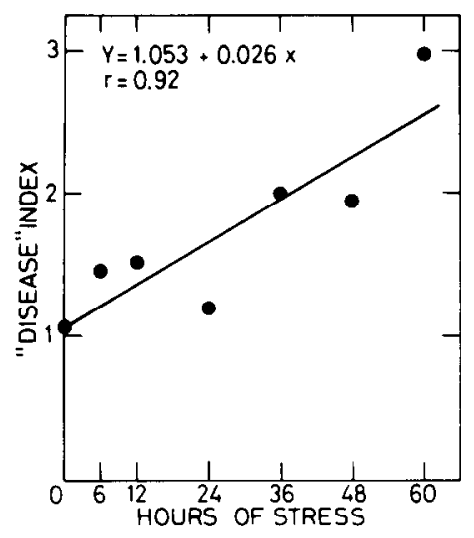

Fig. 3. Effect of length of combined stress on cavity spot severity.

covering the soil surface with wax resulted in plant death after $36 \mathrm{~h}$. Other stresses tested had no apparent effect on cavity spot formation. All experiments were repeated 3 times with similar results.

In three experiments performed in sandy loam soil, cavity spot formation increased proportionally (regression coefficient $r=0.92-0.98$ ) to the length of combined temperature and flooding stresses for up to $60 \mathrm{~h}$ (Fig. 3). Stresses for longer periods resulted in plant death.

Four-month-old plants were exposed to the combined stress of flooding and high temperature $\left(30^{\circ} \pm 2^{\circ} \mathrm{C}\right)$. They were then maintained under normal growing conditions and the appearance of spots was followed for 7 weeks. Appearance of cavity spots increased with time following exposure to stress (regression coefficient $r=0.973$ or $r=0.93$ when the experiment was repeated (Fig. 4). In non-treated control plants, the D.I. remained low (D.I. = $0.39-0.50)$ throughout the experiments. These experiments were repeated in loess soil with similar results.

All carrot cultivars tested were found to be equally susceptible to formation of cavity spot after combined flooding and temperature $30^{\circ} \pm 2^{\circ} \mathrm{C}$ stresses. D.I. ranged from 2.4-2.6 units in treated carrots. Controls remained in the range of $0.46-0.57$ units.

Inoculation of soil with a mixture of bacteria isolated from cavity spots 1 day before exposure of plants to combined stress did not increase cavity spot severity above that obtained with the combined stress only. However, D.I. increased above controls

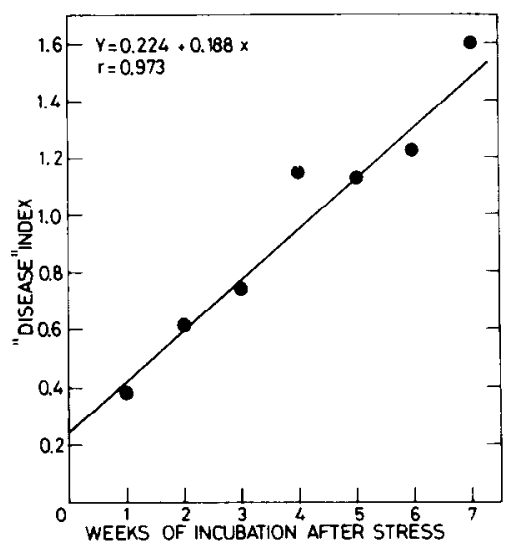

Fig. 4. Effect of incubation time after combined stress on cavity spot severity.

in inoculated carrots that had not been stressed (Table 1).

\section{Effect of $K$ and $N$ fertilization on cavity spot}

Carrots were grown in sandy loam soil with different levels of $\mathrm{K}$ and $\mathrm{N}$ (Table 2). Three levels of $\mathbf{N}$ were added separately to an intermediate $\mathrm{K}$ level, and two $\mathrm{K}$ levels were added to the intermediate $\mathrm{N}$ level. Pots were fertilized 4 days before and 2 days after the combined stress. Pots with or without additional fertilization, and with or without stress, served as controls.

Exposure to combined stress was necessary for all treatments to obtain high "disease" incidence. Relative increases in $\mathbf{N}$ fertilization increased cavity spot formation, whereas relative increases in $\mathrm{K}$ fertilization decreased "disease". However, differences were not statistically significant because of high variability.

\section{Cavity spot formation in partially aseptic soil}

Mature carrots grown in 20 gamma-sterilized Leonard jar assemblies and 20 non-sterilized jars, were exposed to combined stress 6 months after sowing. Four weeks later, plants were examined for cavities. Total bacteria at the time of sowing were $1.5 \times 10^{5} \mathrm{cfu}^{-1}$ soil in non-sterile jars and 0 in soil in sterile jars. At the end of the experiment, hacterial numbers were similar in sterile and non-sterile soil $\left(2.4 \times 10^{5}\right.$ and $1.5 \times 10^{5} \mathrm{cfu} \mathrm{g}^{-1}$ soil, respectively). While a heterogeneous bacterial population existed in

Table 1. Effect of inoculation of soil with a mixture of bacteria isolated from cavity spots on cavity spot formation in carrots

\begin{tabular}{lcc}
\hline \multicolumn{1}{c}{ Treatment to carrots } & "Disease index"a & Disease incidence \\
\hline Untreated & $(0-3)$ & $(\%)$ \\
Inoculated & $0.56 \pm 0.50^{\mathrm{c}}$ & 56 \\
$\begin{array}{l}\text { Combined flooding and } \\
30 \pm 22^{\circ} \mathrm{C} \text { stress }\end{array}$ & $1.28 \pm 0.89$ & 74 \\
$\begin{array}{l}\text { Combined stress and } \\
\text { inoculation }\end{array}$ & $2.48 \pm 0.56$ & 100 \\
\hline
\end{tabular}

${ }^{a} D . I$. was determined 5 weeks after stress.

${ }^{b}$ Soil was inoculated with $50 \mathrm{ml}$ mixture (equal concentrations) of 40 bacterial isolates from cavity spots one day before combined stress.

'In this, and in the following tables, SE of the means, 30 plants per treatment. 
Table 2. Effect of different fertilization conditions on severity of cavity spots

\begin{tabular}{|c|c|c|c|c|}
\hline \multicolumn{2}{|c|}{ Addition of fertilizer } & \multirow[b]{2}{*}{$\begin{array}{c}\text { Stress }^{\mathrm{d}} \\
\text { condition }\end{array}$} & \multirow[b]{2}{*}{$\begin{array}{c}\text { "Disease" severity } \\
(0-3)\end{array}$} & \multirow{2}{*}{$\begin{array}{c}\text { "Disease" } \\
\text { incidence } \\
(\%)\end{array}$} \\
\hline $\begin{array}{c}\text { Potassium } \\
\text { per pot }{ }^{b}(\mathrm{mM})\end{array}$ & $\begin{array}{c}\text { Nitrogen }{ }^{c} \\
\text { per pot }(\mathrm{mM})\end{array}$ & & & \\
\hline 0.05 & 0 & + & $\begin{array}{l}1.53 \pm 0.92 \\
0.62 \pm 0.6\end{array}$ & $\begin{array}{l}87 \\
48\end{array}$ \\
\hline 0.05 & 0.05 & + & $\begin{array}{l}3.00 \pm 0.00 \\
0.59 \pm 0.62\end{array}$ & $\begin{array}{r}100 \\
53\end{array}$ \\
\hline 0.05 & 0.1 & + & $\begin{array}{l}2.58 \pm 0.47 \\
0.77 \pm 0.91\end{array}$ & $\begin{array}{r}100 \\
50\end{array}$ \\
\hline 0 & $0.05^{\digamma}$ & + & $\begin{array}{l}3.00 \pm 0.00 \\
0.65 \pm 0.47\end{array}$ & $\begin{array}{r}100 \\
40\end{array}$ \\
\hline $0.1^{e}$ & 0.05 & + & $\frac{1.70 \pm 1.18}{N D}$ & $\begin{array}{l}100 \\
\text { ND }\end{array}$ \\
\hline 0 & 0 & + & $\begin{array}{l}2.71 \pm 1.07 \\
0.57 \pm 0.78\end{array}$ & $\begin{array}{l}86 \\
43\end{array}$ \\
\hline $\begin{array}{l}\mathrm{KH}_{2} \mathrm{PO}_{4} \text {. } \\
50 \mathrm{ml} \text { to each po } \\
\mathrm{NH}_{4} \mathrm{NO}_{3} \text {. } \\
36 \mathrm{~h} \text { flooding at } \\
\mathrm{KH}_{2} \mathrm{PO}_{4}+\mathrm{KCl} \\
\mathrm{NH}_{4} \mathrm{H}_{2} \mathrm{PO}_{4}+\mathrm{NH}\end{array}$ & $\begin{array}{l}v / v) \\
(1: 7, v / v)\end{array}$ & & & \\
\hline
\end{tabular}

a non-sterile soil (more than 50 different colonies were observed), only one bacterial contaminant could be isolated from the gamma-sterilized soil. The bacterium was partially characterized as a Gram-negative short rod, possibly Pseudomonas sp. In sterilized and non-sterilized soil, D.I. following stress was similar (D.I. $=1.36 \pm 1.15$ and $1.2 \pm 0.45$, respectively). Three attempts to maintain a completely sterile jar during the 6-months cultivation of carrots were unsuccessful.

\section{Bacterial counts during cavity formation}

It was not possible to isolate any bacteria from the inner parts of "diseased" carrots after surface sterilization. Bacterial counts of aseptically cut nonsterilized segments revealed populations ranging from $1.2-1.5 \times 10^{6} \mathrm{cfu} \mathrm{g}^{-1}$ of carrot surface layer tissue (D.I. $=0)$. At D.I. $=1.0$, the bacterial population was $3.5-4.0 \times 10^{6} \mathrm{cfu} \mathrm{g}^{-1}$, whereas at D.I. $=2$, and above, bacterial populations reached their maximum at $4.5-8.5 \times 10^{7} \mathrm{cfu} \mathrm{g}^{-1}$. More than 50 colony types were isolated form cavity spots.

\section{SEM of cavity spot formation}

Scanning electron micrographs of healthy carrot surfaces revealed epidermal cork cells. Several cracks were observed, especially near sites of root emergence. Very few bacterial cells and no fungi were detected. Examination of a very small cavity (1-2 $\mathrm{mm}$ in length) showed few bacterial cells and colonies. The cavity looked as if it had collapsed inside the epidermis layer. A cross-section of the small cavity revealed an internal hole, 9-10 times larger than the outside opening of the cavity. The hole was connected by an opening to the outside cavity. No bacteria were detected in the internal hole. Observation of a full sized cavity (D.I. $=2.0)$ showed masses of bacteria covering the hole walls in a layer several cells thick. In addition, the observations indicated a wide variety of bacterial shapes.
Leakage of substances from carrots after combined stresses and enzymatic activity in healthy carrots and in carrots with cavities

The leakage of electrolytes was enhanced in flooded carrots at temperatures of $30^{\circ} \mathrm{C}$ and above (Fig. 5). Analysis of leaked materials revealed that sugars composed $70 \%$ of the leaking substances, but there were also proteins, amino acids, lipids and minerals. The experiment was repeated 8 times with similar results (Table 3 ).

In the pectinase group there was a marked increase in the activity of pectin and pectate lyase enzymes in crude extracts from the cavity area, as compared to extracts from apparently healthy tissue from "diseased" carrots and from healthy carrots. Polygalacturonase and pectin methylesterase activity markedly decreased in the cavity area and near the cavity (Fig. 6a-d).

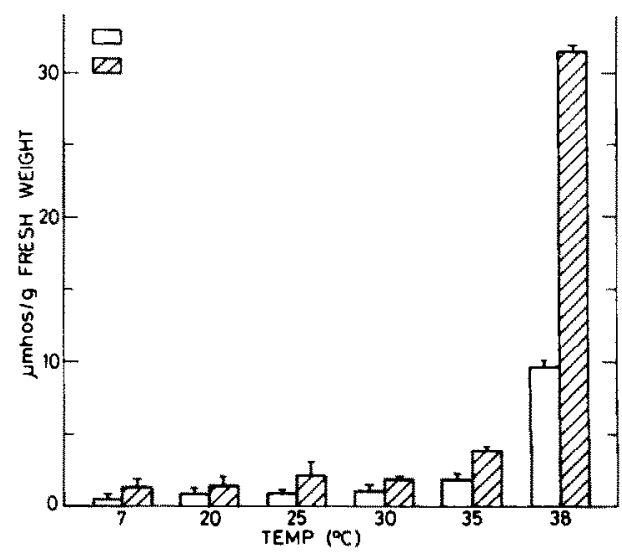

Fig. 5. Electrolytes leakage from flooded $\mathrm{and}$ anot flooded $\square$ carrots at different temperatures. Bars represent standard error. 
Table 3. Leakage of organic and non-organic compounds from carrots subjected to combined stress

\begin{tabular}{lc}
\multicolumn{1}{c}{ Compounds } & $\begin{array}{c}\text { Leakage } \\
\text { (mg/g leakage) }\end{array}$ \\
\hline Organic & \\
Proteins and amino acids & 73.35 \\
Sugars & 700.00 \\
Lipids & 7.75 \\
Total C measured & \\
Total C calculated & \\
& 534.6 \\
Minerals & 470.5 \\
$\mathrm{~K}^{+}$ & \\
$\mathrm{Na}^{+}$ & \\
$\mathrm{NO}_{3}^{-}$ & 54.70 \\
$\mathrm{Mg}^{2+}$ & 13.20 \\
$\mathrm{Ca}^{2+}$ & 10.54 \\
$\mathrm{PO}_{4}^{3-}$ & 1.30 \\
\hline
\end{tabular}

Using direct carbon analysis.

${ }^{b}$ Calculated from the sum of organic compounds that leaked.

In cavity tissue and surrounding areas, protease activity assayed under different $\mathrm{pH}$ values was high as compared to the very low activity that was found in tissue from healthy carrots (Fig. 6e). No cellulolytic activity was detected in healthy or "diseased" carrots.

Peroxidase and polyphenoloxidase activity found in extracts of cavity sites was four-fold higher than in healthy tissue from healthy carrots (Fig. 7a, b). The phenol content of the tissue increased proportionally to the "diseased" severity as measured by determining "disease" index (Fig. 7c).

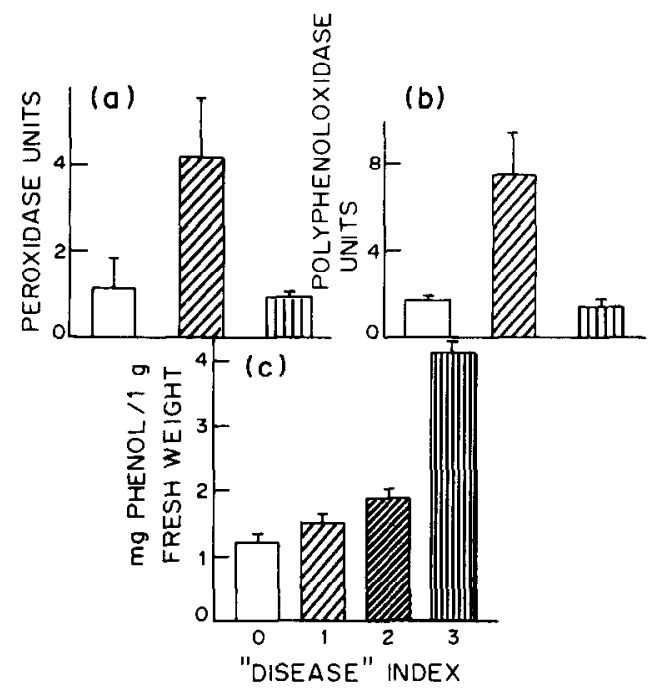

Fig. 7. Specific activity of peroxidase (a) and polyphenoloxidase (b). Symbols and location of tissue are as in Fig. 6. (c) Phenol content was cxtracted from fresh carrot tissue at different "disease" severity levels. Bars represent standard error.
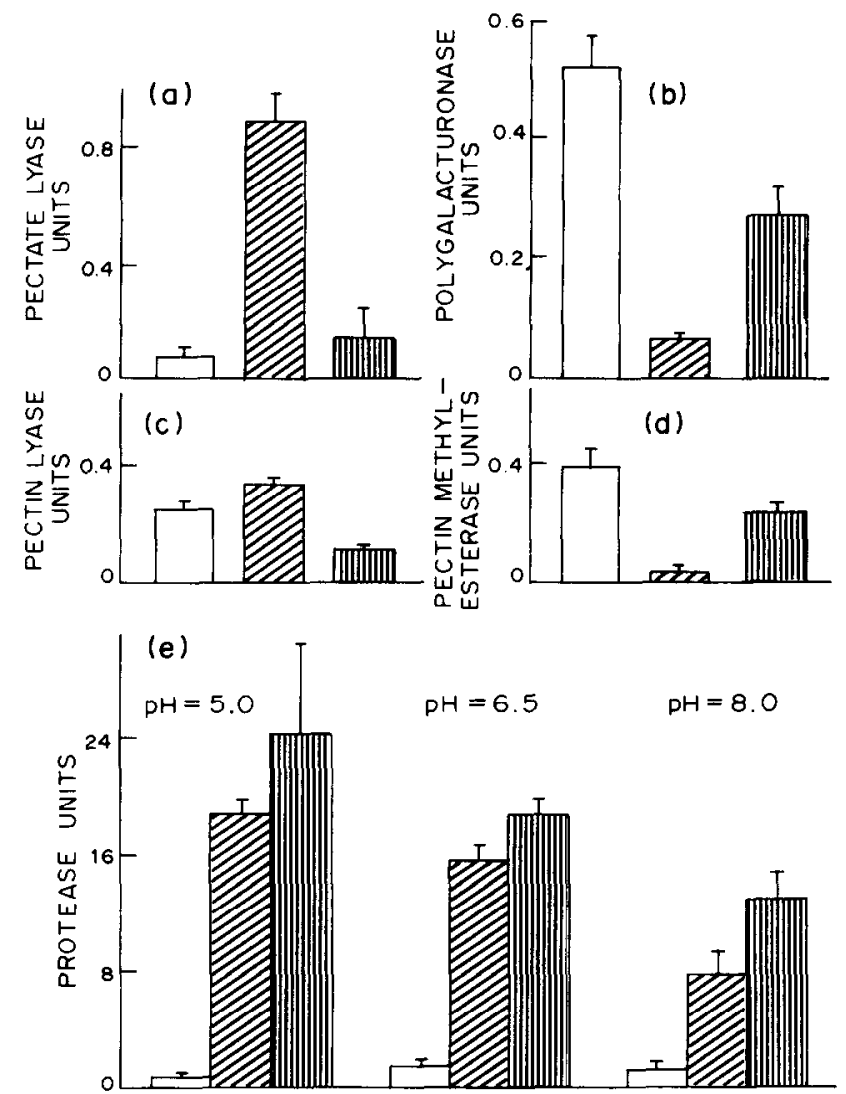

Fig. 6. Specific activity of pectate lyase (a); pectin lyase (b); polygalacturonase (c); pectin methylesterase (d); proteases (e); in healthy carrot $\square$, the cavity spot area ( $5 \mathrm{~mm}$ around the spot) and from apparently healthy tissue near $(1 \mathrm{~cm}$ distance) the cavity spot $\mathrm{Git}$. Bars represent standard error. 


\section{DISCUSSION}

Our results suggest that a combination of physiological and microbial factors are responsible for the formation of cavity spots in carrots. Under controlled conditions, the two major environmental factors causing cavity formation were short periods of flooding and temperatures above $28^{\circ} \mathrm{C}$. These results support field observations in Israel, where severe cavity spot has appeared in flooded areas in irrigated fields during the hot season (Jacobson et al., 1973). Also Perry and Harrison (1979a, b) observed cavity spots to be more common in flat, imperfectly-drained fields with poor soil structure than on other soil types. Perry and Harrison (1979a, b) suggested that lack of oxygen in soil in an inductive factor. However, effects caused by flooding on carrot roots are not necessarily identical to the effects caused by lack of oxygen (Crawford, 1982).

Soil conditions prevailing in Israel do not support the theory that lack of calcium is a key factor in formation of cavity spots (Maynard et al., 1963; Scaife and Clarkson, 1978). We found that cavities were formed in two types of soils in the greenhouse and in three types of soils in the field (E. Soroker, unpublished). These soils contain high levels of both available and unavailable calcium (Ravikovitch, 1981). However, it is possible that a temporary lack of available calcium occurs as a result of flooding, disturbing the balance of ion absorption from the soil solution by the roots (Crawford, 1982).

High temperatures may drastically affect root physiology and microbial activities in the rhizosphere and rhizoplane (Kappen, 1981, Stotzky, 1968). Our study showed that at relatively high temperatures, damage increased with duration of flooding. In addition, damage increased with time following stress.

The fact that the addition to the soil of bacteria that were isolated from cavity spot slightly enhanced cavity formation, and the observation of massive microbial colonization of developed cavities by SEM, indicated that microorganisms participated in the formation of cavities.

Grogan et al. (1961) suggested that microbiological factors played a secondary role in cavity formation and the main factor was not parasitic. On the other hand, Perry and Harrison (1979b) suggested that a pectolytic anaerobic Clostridium was the main causal factor. Lund (1982) questioned those conclusions, noting that as pectolytic clostridia were isolated from only $22 \%$ of the natural cavity-spot lesions examined thus, the requirements of Koch's postulates had not been met. In sterilized Leonard jar assemblies completely lacking any bacteria belonging to the Bacillaceae and containing only a Gram-negative short rod, we have obtained formation of cavity spots after exposing the carrots to the combined stresses of flooding and high temperatures.

High temperatures may cause protein denaturation and especially loss of membrane permeability in roots (Kappen, 1981). Guba et al. (1961) claimed that cavity formation following stress was caused by self-degradation of the tissue situated below the cork cells. Perry and Harrison (1979a) found that cells of the outermost layers of the secondary phloem collapse progressively, leading eventually to rupture of the periderm. Suberin and lignin are deposited in the cell walls of the wounded periderm surrounding the lesion. After carrots were exposed to the combined stress, a sizeable leakage of cell components was observed. The leaking material was high in sugars, which can enrich soil microflora (Rovira, 1970). Observations under SEM indicated that the primary cavity that formed after cell collapse below the epidermal cells was almost completely free of contaminating microorganisms. A marked increase in the number of bacteria counted by the plate method or as observed under SEM occurred only later. This microbial population possessed hydrolytic ahilities (mainly protease and some pectinase activity) which probably caused an enlargement of the microscopic cavity. Enhancement of polyphenoloxidase and peroxidase activities by the forming cavity may be a reaction of the carrot to microbial proliferation, resulting in the accumulation of polyphenols, a phenomenon observed in this work and by Perry and Harrison (1979a).

Our results suggest the following mechanism for cavity spot formation. Environmental stress, the two major components of which are periods of at least $6 \mathrm{~h}$ flooding and temperatures above $28^{\circ} \mathrm{C}$, resulted in physiological injuries to carrots. These injuries caused leakage of mineral and organic compounds, cell collapse and formation of subepidermal cavities. Non-specific bacteria developed in large numbers and helped to degrade the tissue. The defense mechanisms of the plant are activated, arresting the infection. Large amounts of oxidized polyphenol compounds accumulate and cause the brown-black cavity spots of carrot.

Our results and those from studies in the U.S.A. and the U.K., indicate that the phenomenon of cavity spot formation is extremely complex. It is not clear that cultivation of carrots on well-drained soils would, alone, reduce the spread of this "disease" and the damage it causes, as severe damage has been observed in well-drained sandy soils in the Negev area (E. Soroker, unpublished). Therefore, there is not much one can do but to develop resistant carrot cultivars. Improvements in agrotechnical procedures to avoid flooding, anaerobiosis or high temperatures are less likely to be applied successfully in the field.

Acknowledgements - We thank Mrs Naomi Bahat for technical assistance with electron microscopy. This study was supported by a grant from the Vegetable Growers Association, Israel.

\section{REFERENCES}

Bashan Y., Okon Y. and Henis Y. (1978) Infection studies of Pseudomonas tomato, causal agent of bacterial speck of tomato. Phytoparasitica 6, 135-143.

Benefield C. B. (1971) A rapid method for measuring cellulase activity in soils. Soil Biology \& Biochemistry $\mathbf{3}$, $325-329$.

Crawford R. M. M. (1982) Physiological responses to flooding. In Encyclopedia of Plant Physiology New Series, Vol. 12B (O. L. Lang, P. S. Nobel, C. B. Osmond and H. Ziegler, Eds), pp. 453-477. Springer, Berlin.

Finkelstein E., Bashan Y., Okon Y. and Yaakobi C. (1983) Induction of, and crop loss due to, cavity spot of carrots. Phytoparasitica 11, 210 (Abstr.)

Grogan R. G., Zink F. W. and Kimble K. A. (1961) Pathological anatomy of carrot root scab and some 
factors affecting its incidence and severity. Hilgardia $\mathbf{3 1}$, 53-68.

Guba E. F., Young R. E. and Tadao U. (1961) Cavity spot disease of carrot and parsnip roots. Plant Disease Reporter 45, 102-105.

Hobbs G., Williams K. and Willis A. T. (1971) Basic methods for the isolation of Clostridia. In Isolation of Anaerobes (D. A. Shapton and R. G. Board, Eds), pp. 1-23. Academic Press, London.

Jacobson R., Dan C., Yaakobi C. and Sander N. (1973) [Unidentified spots on carrots] Hassadeh 53, 1168-1171 (in Hebrew).

Johanson R. (1954) Anthrone in the estimation of hexose sugars with special reference to pentose interference. Analytical Chemistry 26, 1331-1333.

Johnson M. J. (1949) A rapid micromethod of estimation of non-volatile organic matter. Journal of Biological Chemistry 181, 707-711.

Kappen L. (1981) Ecological significance of resistance to high temperature. In Encyclopedia of Plant Physiology New Series, Vol. 12A (O. L. Lang, P. S. Nobel, C. B. Osmond and N. Ziegler, Eds), pp. 439-474. Springer, Berlin.

King E. O., Ward M. K. and Raney D. E. (1954) Two simple media for the demonstration of pyocyanin and fluorescin. Journal of Laboratory and Clinical Medicine 44, 301-307.

Kritzman G. and Chet I. (1980) The role of phenols in the pathogenicity of Botrytis allii. Phytoparasitica 8, 27-37.

Lcc T. T. (1973) On extraction and quantitation of plant peroxidase isoenzymes. Physiologia Plantarum 29, $198-203$.

Leonard T. J. (1971) Phenoloxidase activity and fruiting body formation in Schizophyllum commune. Journal of Bacteriology 106, 162-167.

Lund B. M. (1982) Clostridia and plant disease: new pathogens? In Phytopathogenic Prokaryotes, Vol. I (M. S. Mount and G. H. Lacy, Eds), pp. 264-283. Academic Press, New York.

Maynard D. N., Gersten B., Young R. E. and Verncll H. F. (1963) The influence of plant maturity and calcium level on the occurrence of carrot cavity spot. American Society for Horticultural Science Proceedings 83, 506-510.

Nasuno S. (1975) Pectin degradation by phytopathogenic and saprophytic bacteria. In Proceedings of the First Workshop on Phytobacteriology (R. N. Goodman, Ed.), pp. 34-37. Univ. of Missouri, Columbia.

Nasuno S. and Starr M. P. (1967) Polygalacturonic acid trans-eliminase of Xanthomonas campestris. Biochemistry Journal 104, 178-185.
Perry D. A. and Harrison J. G. (1977) Pectolytic anaerobic bacteria cause symptoms of cavity spots in carrots. Nature 269, 509-510.

Perry D. A. and Harrison J. G. (1979a) Cavity spot of carrots. I. Symptomatology and calcium involvement. Annals of Applied Biology 93, 101-108.

Perry D. A. and Harrison J. G. (1979b) Cavity spot of carrots. II. The effect of soil conditions and the role of pectolytic anaerobic bacteria. Annals of Applied Biology 93, 109-115.

Ravikovitch S. (1981) The Soils of Israel, Formation, Nature and Properties, 489 pp. Hakibbutz Hameuchad, Tel-Aviv (in Hebrew).

Rinderknecht H., Geokas M. C., Silverman P. and Haverback B. J. (1968) A new ultrasensitive method for the determination of proteolitic activity. Clinica Chimica Acta 21, 197-203.

Rovira A. D. (1970) Plant root exudates and their influence upon soil microorganisms. In Ecology of Soil-Borne Plant Pathogens (K. F. Baker and W. C. Snyder, Eds), pp. 170-186. Univ. of California Press, Berkeley.

Ruben D. M., Frank Z. R., Chet I. and Sklan D. (1981) Changes in the chemical composition of oospores of Pythium aphanidermatum during biomodal germination. Canadian Journal of Microbiology 27, 536-543.

Scaife M. A. and Clarkson D. T. (1978) Calcium-related disorders in plants-a possible explanation for the effect of weather. Plant and Soil 50, 723-725.

Scaife M. A., Burton A. K. and Turner M. K. (1980) Cavity spot of carrots-an association with soil ammonium. Communications in Soil Science and Plant Analysis 11, $621-628$.

Sedmak J. J. and Grossberg S. E. (1977) A rapid, sensitive and versatile assay for protein using Coomassie brilliant blue G-250. Analytical Biochemistry 79, 544-552.

Stotzky G. (1968) Relevance of soil microbiology to search for life on other planets. In Advances in Applied Microbiology, Vol. 10 (W. Umbreit and D. Perlman, Eds), pp. 17-54. Academic Press, New York.

Vincent J. (1970) A Manual for the Practical Study of Root-nodule Bacteria. Blackwell, Oxford.

Wang M. C. and Keen N. T. (1970) Purification and characterization of endopolygalacturonase from Verticillium albo-atrum. Archives of Biochemistry and Biophysics 141, 749-757.

Watanabe F. S. and Olsen S. R. (1965) Test of an ascorbic acid method for determining phosphorus in water and $\mathrm{NaHCO}_{3}$ extracts from soil. Soil Science Society of America Proceedings 29, 677-678. 